\title{
Posthumanism or Ecohumanism? Environmental Studies in the Anthropocene
}

Hubert Zapf ${ }^{1}$

\begin{abstract}
The paper discusses two of the currently most influential discourses in the environmental bumanities, posthumanism and the Anthropocene, in the light of the concept of 'ecohumanism' suggested by the title of the present new journal. This concept resonates with the approach of a cultural ecology in literary studies and the environmental humanities, which takes an in-between stance between a radically ecocentric posthumanism and a narrowly anthropocentric bumanism. The paper addresses four different domains in which such an ecologically redefined bumanism can productively respond to some of the paradoxes and unresolved questions in current environmental studies: (1) the ambiguous role of science and the search for a valid basis of scholarly truth-claims; (2) the question of the subject, and of personal vs. impersonal agency; (3) the role of the archive and of the cultural past in Anthropocene thought and writing; and (4) the relation of the buman and the non-human, and of the future of (eco-)bumanism in the Anthropocene.
\end{abstract}

Keywords: Ecohumanism; Posthumanism; Anthropocene; Cultural Ecology; Environmental Humanities; Literary Studies

\section{Introduction}

In my paper, I would like to raise a few questions which relate to two of the currently most influential discourses in the environmental humanities, posthumanism and the Anthropocene, in the light of the concept of 'ecohumanism' suggested by the title of the present new journal. In focusing on "issues beyond the ecocentric-anthropocentric binary" (CfP Editors, 2021), this ecological-humanist perspective resonates with the approach of a cultural ecology in literary studies and the environmental humanities (Zapf, 2016a, 2016b). It seems to me that, much like cultural or 'transcultural' ecology (Bartosch, 2019, 2021), such a perspective takes an in-between stance between a radically ecocentric posthumanism and a narrowly anthropocentric humanism. Like posthumanism, it addresses the challenge for sustainable futures by the global ecological crisis and the derangement of traditional human scales of perception, time, space, and agency in the Anthropocene from an awareness of the lifeenabling co-agency of the more-than-human world in cultural evolution and creativity. Yet it envisions no simple overcoming or rejection of an allegedly obsolete humanist past but rather the quest for a new, ecologically aware, and transculturally open humanism that is both critical of historical shortcomings yet can also profit from the rich proto-ecological archives of the

${ }^{1}$ Prof. Dr. Hubert Zapf, Professor of American Studies and Co-Director of Environmental Humanities, University of Augsburg, Germany. E-mail: hubert.zapf@philhist.uni-augsburg.de. 
humanist-literary tradition (Meireis and Rippl, 2019, Schaumann and Buchholz, 2021). It goes without saying that within the limited space of this essay, I can only touch upon these issues, each of which would require substantive and extensive elaboration. Instead, I will address in a rather pointed, thesis-like form some of the unresolved paradoxes of current environmental debates, from which the shift from a posthumanist to an ecohumanist perspective might appear plausible.

In terms of their disciplinary origins, posthumanism and the Anthropocene as two key discursive markers of recent environmental debates have emerged from symmetrical developments. While the concept of the Anthropocene has been adapted to the humanities from the natural sciences, notably geology, the concept of posthumanism developed from within the humanities themselves as a critique of their own inherited traditions, especially the notions of autonomous human agency, the self-determined personal subject, the hierarchical separation of culture from nature, and of human exceptionalism in relation to other life forms. And while the concept of the Anthropocene introduces the human factor as a new element into the scientific description of a hitherto non-humanly defined sequence of geological eras, the concept of posthumanism opens the humanities to new ways of thinking about the category of the human in the context of non-humanist disciplines such as geology, biology, physics, earth sciences, and ecology (for critical-differentiated assessments of posthumanism and the Anthropocene, see e.g. Iovino and Oppermann, 2015, Emmett and Lekan, 2016, Comos and Rosenthal, 2019, Horn and Bergthaller, 2019). What this implies is, positively speaking, a potentially highly productive cross-disciplinary process of mutual fertilization between formerly separated knowledge cultures. More critically viewed, it can lead to a proliferating circulation of undifferentiated hybrids (such as naturecultures, bodyminds, material-semiotic, onto-ethico-epistemological [Mamic, 2016], ethico-onto-epistemologal [Geertz and Carstens, 2019] and so forth) which highlight the postulate of inextricable ontological 'entanglements' but tend to neglect the inevitable tensions and paradoxes that characterize the interdisciplinary challenges of the environmental humanities.

Among these paradoxes and tensions, I would like to single out the following points as a set of questions that in my view need to be newly addressed in an environmental studies context:

\section{The ambiguous role of science}

After the fundamentalist critique of science in earlier environmentalism as the "root cause of current ecosystem depletion in historical conjunction with technology, industrialization, and urbanization" (Heise, 1997, p. 4), science has been reaffirmed in environmental cultural studies in the $21^{\text {st }}$ century in the context of climate change debates, in which the denial of global warming became a highly politicized form of postfactual discourse that could only be countered by a however critical and provisional acknowledgement of fact-based environmental science. One conclusion from this is that truth is not just a social construction, even if science and technology studies (STS) show that it is intricately entwined with specific historical-social conditions (Jasanoff, Markle, Petersen, Pinch, 2007). Rather, the open-ended search for truth that includes correcting one's assumptions in the face of new evidence remains a valid basis of any responsible project of scientific knowledge.

In many directions of the environmental (post-)humanities, the sciences are explicitly invoked and productively integrated into transdisciplinary research agendas, and in the work of some of their leading proponents, this dialogue has been a central feature and has opened up highly 
innovational areas of scholarly exploration and creativity - from Karen Barad's new materialist interpretation of quantum physics (Barad, 2007) to Jane Bennett's inquiries into the vibrancy of matter in human-nonhuman assemblages (Bennett, 2010), Serpil Oppermann and Serenella Iovino's translation of material-scientific knowledge into ecocriticism (Oppermann, 2015, Iovino, 2017), Wendy Wheeler's fusion of literary theory with insights from biosemiotics (Wheeler 2016), Ursula Heise's work at the interface of technological media, the environmental imagination, and multispecies sciences (Heise, 2017), to Latour-inspired actornetwork and STS cultural and literary studies (Latour, 2005). Also, this intensified exchange between science and new materialist-posthumanist scholarship has significantly influenced artistic creativity in the Anthropocene, which has developed manifold new forms of experimental boundary-crossing from the inspiration of such theories.

Yet for all the intricate arguments derived from diverse scientific sources, there is sometimes an underlying ambivalence about the role and status of the (natural) sciences in some parts of posthumanist studies which, influenced by Foucauldian discourse analysis, tend to conflate scientific truth claims with the technological-institutional power constellations with which they are 'entangled.' However, while knowledge is obviously in many ways interrelated with various forms of institutionalized power in terms of gender, class, ethnicity, speciesism, etc., it cannot simply be identified with such power relations, as a common misunderstanding of Foucault would suggest - a misunderstanding which Foucault himself felt he had to correct against reductionist readings of his work, arguing instead that knowledge can indeed gain validity independent of its institutional and other conditions of emergence. In an interview with Revista international de filosofia, Foucault mentions not only the more obvious example of mathematics but also the examples of psychiatry and anthropology in his observation that scientific validity remains an important criterion in these disciplines beyond their entanglement in institutional power structures (Foucault, 1984). Scientific knowledge in this sense is no mere ideological product of 'Western' science, capitalism, colonialism, or anthropocentrism, but an open-ended process of publicly shared critical-explorative thinking across historical-cultural divides. That is the meaning and function of its practices of publication and scholarly exchange in the first place: to make it accessible also to those that do not participate in the conditions of its emergence. This access to truth and knowledge is of course not the exclusive domain of the institutionalized sciences but can also be achieved by other, communal, or personal forms of 'citizen science', which have gained increasing importance in the transdisciplinary pluriverse of environmental studies. There are different ways and cultural forms of achieving and communicating ecological knowledge, including alternative, indigenous knowledge cultures that in their translation into 'cosmopolitical' environmental studies significantly extend and enrich 'Western' scientific cultures (Adamson, 2012). As George Nicholas writes: "Science is a multicultural enterprise that benefits from and indeed requires competing views. Indigenous observations, perspectives and values enrich, not threaten, our collective knowledge of the world." (Nicholas, 2019)

To be sure, the critique of conceptual biases or exclusions in established scientific practices is clearly vital and epistemically relevant, such as in undifferentiated uses of the term Anthropocene, in which the asymmetrical distribution of the human impact on the planet and the concomitant problems of environmental justice are unduly marginalized. Yet such critical differentiations as well as the proposal of alternative concepts like Capitalocene, Plantationocene, Chthulucene (Haraway, 2016) etc., are enabled by the scientific proposition 
and circulation of the Anthropocene concept in the first place, and must themselves strive to seek acceptance within intersubjective scholarly exchanges based on convincing argument and evidence. At the same time and for this very reason, the wholesale discrediting of such propositions or even of entire disciplines seems counterproductive. Thus when geology, the discipline from which Anthropocene research has been initiated, is characterized as little more than a scientific version of structural white racism whose 'grammar' is shaped by its extractivist-colonial heritage (Yusoff, 2019), such generalizing judgements fail to distinguish between historical conditions and the validity of the evidence-based knowledge the geosciences have supplied as indispensable reference for current Anthropocene debates (Steffen et al., 2015). The problem is not such critical contextualization as such but a tendency to overstate the sociopolitical context-conditions of scientific knowledge and to underestimate the empirical results and intersubjective plausibility of its findings. In this sense, I agree here with Greg Garrard when he describes the challenge for the environmental humanities as "de-idealizing without delegitimizing science." (Garrard, 2017)

This need of a more balanced historical reassessment extends to the enlightenment project more generally, which is sometimes as a whole discredited for its anthropocentric ideology, to the point that it completely loses any legitimacy as a potential source of critical reason and emancipatory thought. Instead, it seems more helpful to interpret the dialectic of enlightenment, with its breakthrough achievements as well as its darker, irrational side, as a symptom of the "unfinished project" of modernity (Habermas, 1990). Ritchie Robertson likewise points out the blind spots but also the long-term significance of enlightenment thought in his wide-ranging systematic reassessment of the legacy of the enlightenment (Robertson, 2021). From an ecological point of view, such a reassessment of the enlightenment needs to incorporate not just its own self-critique from an awareness of the disastrous rebounds of self-reflexive modernity in the sense of Ulrich Beck's world risk society (Beck, 1998) but to continually renew itself in the dialogue with alternative notions of enlightenment provided by non-Western and indigenous knowledge cultures (Johnson, 2005).

\section{The question of the subject, of personal vs. impersonal agency}

Complementary to their deconstruction of objectifying science from a relational ontoepistemology, influential versions of posthumanism at the same time aim at dismantling the human subject and personal human agency in favor of impersonal, collective, institutional, medial, technological, material, or ecological forces and networks. Cary Wolfe argues from a critical animal studies perspective that "the humanist concept of the subject is inseparable from the discourse and institution of speciesism..."(Wolfe 2003, 43) In the view of speculative object philosophy, " $[\mathrm{H}]$ umans, far from constituting a category called 'subject' that is opposed to 'object', are themselves one type of object among many."(Bryant, 2011, 49) And in the work of Donna Haraway, the dissolution of the boundaries between human, animal, and machine in her figure of the cyborg amounts to a "rejection and a reconfiguration of the values of the traditional humanist subject." (Bolter, 2016)

The question is whether this erasure or at least radical decentering of the human subject and of personal agency in favor of impersonal relational ontologies is convincing. While the critique of the liberal humanist subject in poststructuralism and posthumanism has provided valuable insights into linguistic, biopolitical, material, and other limitations of individual selfdetermination, it has not really succeeded in eliminating the subject from the humanities in 
either theory or practice. Instead, as Stefan Herbrechter pinpoints it in the characteristically deconstructionist mode of his 'critical posthumanism,' the subject remains an impossible but necessary assumption: “... anything human (including the post-, trans- or inhuman) is (literally and letterally, that is through and in language) unthinkable without a notion of subjectivity." (Herbrechter, 2012, 336)

Meanwhile, in interdisciplinary encounters with the hard sciences, the critical-hermeneutic methodology of the humanities, the Kultur- und Geisteswissenschaften with its combination of historical-textual analysis and reflexive (inter-)subjectivity, remains indispensable as a form of scholarly practice that offers its own productive form of ecocultural knowledge, in which concepts like personal agency, alterity, narrativity, memory, or empathetic imagination remain valid differentia specifica that elude the depersonalized approach of the natural sciences and instead represent a rich epistemic, ethical, and aesthetic potential that the environmental humanities can contribute to contemporary transdisciplinary knowledge cultures (see e.g. Meireis and Rippl. 2019). Subjectivity is defined in different ways in philosophical approaches, and not least phenomenology with its concepts of embodied subjectivity and lived experience has become one of the inspiring influences on contemporary ecotheory (Böhme, 2016). The extension of the empathetic imagination from human to nonhuman life forms that recent approaches advocate (e.g., in the cognitive eco-narratological approach of an affective ecology, Weik von Mossner, 2017), nonetheless also presupposes the assumption of personal human agency, in this case, of writers and readers - even while this personal agency is always embedded, interconnected, and never fully autonomous.

In some posthuman approaches, a return of the subject is recognizable to an extent. Thus Rosi Braidotti writes: "One needs at least some subject position: This need not be either unitary or excessively anthropocentric, but it must be the site for political and ethic accountability, for collective imaginations and shared aspirations." (Braidotti, 2013, 102) Yet more often than not, such interventions are submerged by an overriding "anti-humanist" impulse (Braidotti) that tends to conflate the egocentric subject of capitalist power structures with the much more differentiated, self-aware, and ethically responsive concept of the subject in philosophical traditions such as the Critical Theory of the Frankfurt School, which precisely developed from the critical reflection and dialectic overcoming of those reductionist notions of the bomo oeconomicus. Even more in line with an ecohumanist perspective than in the negative dialectics of Critical Theory are conceptions of the subject such as in Hartmut Rosa's theory of resonance (Rosa 2016). Rosa takes up the critique of impoverished human-world relations by the Frankfurt School but complements its negative focus on the radically alienated subject with a more affirmative and holistic notion of the subject, whose rich potential of resonant mutuality in its interaction with the environment is realized in various intellectual, creative, and bodily forms. Rosa's subject is a fluid, communicative, and embodied subject always already embedded in mutually defining existential interrelations with the world. Yet within this relational conception, his postcritical theory nevertheless assumes an eigendynamical status and agency of the subject in two major respects: "Subjects are, for one thing, those entities which make experiences...; and they designate, secondly, the site where psychic energy materializes in the form of motivation, where in other words intentional agency becomes manifest." (Rosa 2018, 65, my trans.)

A contemporary writer and intellectual, in whose thought and work the double recognition of both singular individuality and co-existential relationality as a condition of all human speech, 
writing, and knowledge becomes especially pronounced is Siri Hustvedt. In her seminal address to the 2012 German American Studies Convention, Hustvedt made a strong point for the role of the personal self and the inevitable presence of the first person singular not only in literary but in scientific knowledge (Hustvedt, 2012); while her whole writing is at the same time informed by a relational concept of the subject as an inherently co-existential being in the sense of Hegel and Levinas: "I am because you are", as she reformulates the cartesian definition of the autoreflexive self into an ecology of mutually interdependent yet distinctly unique selves in her novel What I Loved (Hustvedt, 2003, 91).

\section{Continuity vs. discontinuity - The role of the archive in Anthropocene thought and literature}

There seem to be different forms of responding to the Anthropocene in theory, art, and literature - one is the fundamental break with an anthropocentric cultural past, which, as Timothy Clark argues in Ecocriticism on the Edge, calls for completely new, quasi avant-garde forms of experimental art and literature (Clark, 2015); the other is a new relevance of cultural memory (Assmann, 2019) and of the archive of past thought and creativity for alternative forms of culture-nature communication (Schaumann and Buchholz, 2021).

It has been claimed that in view of the unprecedented scale of the environmental, economic, intellectual, and ethical challenges of this new geo-historical era, not only political agendas and sociocultural practices need to be drastically changed, but inherited categories of literature and literary knowledge need to be adjusted to a posthuman condition which limits the range of human agency and entangles the lives of individuals in hyperreal interdependencies that exceed their cognitive and emotional grasp. Inasmuch as all traditional literature and storytelling are based on such human categories of perception and experience, this fundamental crisis in this view requires completely new forms of literary representation and communication including the extension of human to geological time-space, decentering the human subject, acknowledging the independent agency of the nonhuman, and translating into aesthetic form the multiscalar nature of the problems in which these interconnected actor-networks in the Anthropocene are enmeshed. (Zapf, 2019, p. 6)

However, while such ideas have provided fruitful impulses for both theory and various forms of creative practice, a purely oppositional, radically discontinuous view of the relation between a 'humanist' literary past and a 'posthumanist' Anthropocene not only neglects the significance of cultural memory for any sustainable vision of the present and future (Assmann, 2019). It also eclipses the long history of the ways in which imaginative literature has been dealing with crisis, disaster, and, indeed, with alternative forms of human-nature communication. In its experimental innovations, the literature of the Anthropocene conspicuously draws on the repertoire from various historical, cultural and literary archives in its creative response to the challenges of this new global mega-crisis of human history. (Zapf, 2019, p. 7)

In many cases, in fact, the two impulses of a radical aesthetic experimentalism and of the creative recycling of the literary archive seem to go hand in hand in a cultural-ecological imagination which combines contemporary with deep-time perspectives, human with nonhuman agency in ever new productive transformations (Zapf, 2021). Thus for example, Buddhism as a source from the long-term cultural archive of the world has turned out to be newly relevant to Anthropocene thought and art (Gaard, 2015). Buddhism, of course, already had a significant history of reception in the West and became an inspirational source for 
ecological thought in American transcendentalism, in Beat poets like Gary Snyder, or in Fritjof Capra's fusion of Zen Buddhism with quantum physics. In European literary history, the romantic notion of Natursprache has gained new attention as anticipating insights of current biosemiotics, one of the cutting-edge directions of the environmental humanities. As Kate Rigby among others has pointed out, the translation of the language of nonhuman nature into forms of human creativity, as suggested by the idea of Natursprache, has been one of the important, if not adequately recognized, contributions of imaginative texts to ecological knowledge and communication (Rigby, 2016).

In a significant body of Anthropocene poetry, the archives of literary history are conspicuously present not only in manifold intertextual references to various sources from modern literature, philosophy, and science but in motifs from the deep-time memory of culture-nature-coevolution such as metamorphosis, elemental poetics, or human-nonhuman hybrids. An example is the collection of contemporary German poetry Lyrik im Anthropozän (Poetry in the Anthropocene), a spin-off from the 2014-2016 exhibition on the Anthropocene at the Deutsches Museum in Munich that was co-organized with the Rachel Carson Center for Environment and Society (Bayer and Seel, 2016). As Axel Goodbody writes in his essay in the collection, "contemporary poets (such as Jan Wagner, Silke Scheuermann and Nico Bleutge) have drawn from the archive of past forms and treatments of themes in their creative response to the Anthropocene." (Goodbody 2016, p. 303, my trans.) What seems to find expression here is a new form of re-generative creativity that overcomes the modernist creed of autonomous individualistic creatio ex nibilo but nevertheless draws on the potential of art and literature as a personally accessible source of renewable energy in culture, which constitutes its own form of sustainable cultural practice.

This recycling of the archive produces "ecologically sensitive, self-reflexive forms of writing" (Goodbody 2016, p. 303), which address topics like species depletion and the devastations of global capitalism not in a one-dimensional, didactic manner but in multifaceted and polysemic forms, whose openness to the active personal co-interpretation of readers is one of their constitutive elements. The creative response to the Anthropocene in experimental ecopoetics offers manifold examples for this janus-faced form of re-generative creativity, which is looking forward and backward at the same time.

One out of numerous examples from Anglophone ecopoetry would be Evelyn Reilly's collection Echolocation (2018). Reilly calls her echolocations poetic navigations in the dark, a form of writing and communicating as if in blindness or under water, and stages her performative texts as poetic dialogs in a deep-time universe and multi-voiced underworld of literature. The long poem "Lesser Leviathans" performs an extended dialogue with quotations from Melville's Moby-Dick in numbered and fragmentary comments in three columns, with Melville's text in the middle, and with significant passages marked in bold type centering around the encounter of humans and whales as an imaginative journey into the coevolutionary origins of both life and literature. The collection ends with the eponymic poem "Echolocation" in 29 numbered parts, a manifesto-like epigrammatic assemblage of citations from the echochamber of literature and cultural philosophy - where echolocation in this sense is also a form of living intertextuality, demonstrating the continuing value of literature as a sustainable source for always new adaptations and transformations. 


\section{Posthumanism or Ecobumanism? Environmental Studies in the Anthropocene}

In the genre of the novel, a recent, particularly instructive case is Richard Powers' The Overstory (2018). The novel is an experimental yet eminently readable text, which combines linguisticartistic virtuosity with environmental engagement. From multiple perspectives and across different generations, it tells the story of the relationship between humans and trees as the deep history of a life-enabling symbiosis, which is being fatally disrupted by the ecological crisis. In the fate of nine interrelated characters, the ongoing destruction of the remaining Redwood Forests in the American West becomes intensely felt in personal dramas of involvement and civil resistance. Personal experiences are closely interwoven with ecological science but also with questions of philosophy, religion, cultural history, ethics, the media, and the all-pervading digitalization of society. Between everyday life and outsider existence, scientific analysis and violent environmental activism, interpersonal relations and totem-like alter-ego relations with trees, the nine separate lives gradually come together under the overarching 'roof', the 'overstory' (of leaves or needles) of the narrative. While the novel's structure appears decentered and disrupted by chance-like turns and spatial-temporal leaps, it simultaneously follows a connective pattern of continuous ramifications in the manner of a plant-like autopoiesis, bringing the manifold microstories of environmental activities together in analogy to the growth of a tree. The book chapters lead from the "Roots" to the "Trunk" and the "Crown", and ultimately to "Seeds," in an ending which indicates a regenerative perspective for the future, a perspective of "slow hope", as Christof Mauch would call it (Mauch, 2019) - even if this remains only a utopian vision in the face of the escalating environmental destruction that the novel depicts. In this, The Overstory continues an aesthetic practice pointing back to romanticism at least, which takes the autopoiesis of nature as a model of textual autopoiesis. Among the most influential examples is Goethe's Metamorphosis of Plants, which has become a standard reference in ecocriticism and in literary plant studies (Goodbody, 2015). But the motif also occurs in less obvious contexts, such as in Herman Melville's metafictional comment in Moby-Dick, which couples oceanic imagery of fluidity with the imagery of vegetal growth: "Out of the trunk, the branches grow; out of them, the twigs. So, in productive subjects, grow the chapters.' (Melville, 1958 [1851], 232). The Overstory takes up such motifs and translates the affinity between aesthetic and ecological processes into the conditions of the Anthropocene.

The novel thus responds to contemporary theoretical discourses in a double way: By radically decentering a unified approach to the ecological crisis into divergent nodes and ramifications in the sense of a rhizomatic process a la Deleuze/Guattari; and at the same time recentering these elements into the emergent autopoetic system of a tree-like structure. What the novel does among other things, then, is reconfiguring the relation between rhizome and tree, process and system, horizontal and vertical axes of thought and life that has often been presented as a binary opposition in theoretical discourses, as mutually conditioning forces in an emerging fictional ecosystem, in which the critical deconstruction of unsustainable cultural practices that threaten the very foundations of human and nonhuman survival takes itself the form of a sustainable counterdiscourse.

\section{The relation between the human and the nonhuman, or: The future of (Eco-)Humanism in the Anthropocene}

Again, what seems required in all these questions relating to the Anthropocene, is a thinking not in either/or binaries but in relational complexities in terms of both/and - of personal agency inextricably embedded in transpersonal interdependences, of actor-network- 
assemblages between human and nonhuman agencies in which the assumption of responsible human agency nevertheless remains a necessary premise of ecological thought and engagement.

The rhetoric of posthumanism sometimes suggests - and may be misunderstood in the wider public beyond academia in this sense - a simple overcoming or even complete discarding of humanism when it rather seems appropriate more carefully to differentiate what we understand by the term. Against reductionist generalizations about humanism as a denigratory concept we should ask about its historical blind spots but also its indispensable legacy at a time when basic achievements of knowledge, values, democracy, of commonly shared principles in ethics and human rights are at risk in a political climate of regressive populist nationalisms that have nothing to do with, in fact blatantly contradict the traditions of an enlightened, transculturally open humanism. The humanism against which radical posthumanists polemize is a narrow form of humanism mostly associated with antireligious dogmatism and monocultural Western dominance. However, the history of humanism in a wider sense is much more diverse and differentiated and has itself a legacy that in contemporary interpretations can have continued relevance (Nida-Rümelin, 2016). I cannot go into this rich and contested history in any serious detail. In fact, it would have to be carefully written anew in the context of the current developments we are dealing with in our disciplines. Suffice it to say that such a more balanced history of humanism would have to include not only European humanism since the Renaissance, which in turn revived traditions of proto-humanist thought in classical Greece and Rome, up to the Modern Humanist Manifestos of the $20^{\text {th }}$ century, but also such various manifestations as secular humanism, religious humanism, LGBTQ humanism (https://www.lgbtqhumanists.org/about-thelgbtqha, 2021) or digital humanism (Nida-Rümelin, 2018, Adamson, 2018). This kind of polyhistorical and transcultural humanism is not based on one hegemonic-normative notion of the Anthropos which would exclude marginalized or subaltern voices. Differences between humans on basis of personality and culture, or on the other hand also on basis of power asymmetries, discrimination, racism, sexism, and so forth, are not ignored from this transcultural humanist perspective: On the contrary, they appear in an even sharper light as violations of those commonly shared ethical principles, without which a substantive critique of those violations would indeed not be possible.

In postcolonial studies, Edward Said has certainly been one of the most influential theorists, whose book Orientalism exposed the ideological projection of Otherness onto the East in European thought and writing and opened the way for the critical deconstruction of such projections and for decolonizing dominant discourses on non-Western cultures (Said, 1978). At the same time, however, Said's aim was not in the end the perpetuation of cultural divides but a transcultural exchange grounded in humanist principles in a broad sense, which he summarized in his 2004 book Humanism and Democracy (Said, 2004). There, he saw a special task for literary and cultural studies in such cross-cultural humanist transformations, since "words are vital agents of historical and political change." (Said, 2021) Said extended these ideas to other arts and especially to music, a field in which he had a special expertise. In his collection of essays, Music at the Limits, he interprets the cultural work of music in similarly transformative ways (Said, 2009), and his long-standing cooperation with the pianist and conductor Daniel Barenboim resulted in the foundation in 1999 of the West Eastern Divan orchestra. Inspired by the poetic encounters between West and East in Goethe's dialogue 


\section{Posthumanism or Ecohumanism? Environmental Studies in the Anthropocene}

with the Persian poet Hafiz in West-östlicher Divan (1819), the project has meanwhile been institutionalized in an Academy in Berlin that brings together musicians from Israel and the Arab world and is accompanied by a writer's program that aims at such mutual (ex-)change. In his programmatic statement for the project, Said writes: "Humanism is the only - I would go so far as saying the final - resistance we have against the inhuman practices and injustices that disfigure human history. Separation between peoples is not a solution for any of the problems that divide peoples. And certainly ignorance of the other provides no help whatever. Cooperation and coexistence of the kind that music lived as we have lived, performed, shared and loved it together, might be." (Said, 2021) This form of humanism Said envisions is an inclusive, non-dogmatic and indeed utopian form of humanism, which as I believe should not be dismissed but rather be incorporated in an ecologically extended conception of the humanities.

This ecological redefinition of humanism does not mean a radical dehierarchization of the human-nonhuman relationship in a 'flat ontology.' Of course, the well-being of humans is inseparably linked with the well-being of the planetary ecosystem and the well-being of other species, as multispecies thinking in its various forms reminds us (Heise, 2017). And the task of the environmental humanities must be to overcome the destructive objectification of nature as a deeply engrained mindset and instead to aim at a sustainable restoration of the health and diversity of natural as well as cultural ecosystems within the overall goal of an ecological transformation of society. The problematic implication of a complete dehierarchization and 'democratization' of the human-nonhuman relationship however would be that urgent socio-ecological issues such as environmental justice, slow violence, the suffering of disempowered people and communities through waste, toxicity, poverty, and environmentally induced health problems would be relativized in favor of the recognition of the 'equal rights' of nonhuman agencies. More often than not, climate change novels address these very problems. In Amitav Ghosh's The Hungry Tide, for example, the protection measures for the Bengal tigers clash with the survival interests of indigenous people that are forcefully removed from their islands and whose lives are sacrificed to an - however instrumentalized - agenda of environmental protection (Ghosh, 2004). In Margaret Atwood's Maddaddam Trilogy, the bioengineer Crake wipes out the whole existing human species in a pharmaceutical mass murder to replace it with a genetically engineered, environmentalfriendly posthuman species to save the earth from destruction by a hopelessly greedy and egocentric humanity (Atwood, 2003, 2009, 2013). The ethical challenge of the trilogy consists in the implication that the consequences of such a radical posthuman ecocentrism are as unsettling as the dystopian scenarios of a capitalist civilization that the novels depict.

In view of the current pandemic, it is evident that the global health crisis of Covid-19 is intricately connected with the planetary environmental crisis. At the same time, it is equally evident that, while recognizing ecological interdependency and the shared terrestrial fate of all species and material agencies in the earth's critical zone (Latour, 2018), the situation does not in all earnest call for equal rights of humans and the virus but involves an ethical hierarchization which implies that the health and survival of humans be protected against the agency and survival interest of the virus. In biological terms, the immune system of the body tries with all means to fight off the potentially deadly attack of the virus, and vaccination supports the body in this struggle. In sociopolitical terms, the measures that are being taken against the paralyzing impact of the pandemic - however insufficient or socially unbalanced they may be - are in principle oriented on this goal. In scientific terms, not only virological 
research that has led to the production of efficient vaccines but also research in the environmental health sciences, which is explicitly based on the premise that human health and the health of nonhuman ecosystems are vitally interdependent, nevertheless have as their primary focus the health and survival of humans. For all our heightened awareness of 'symbiotic evolution' (Margulis, 1998), of 'transcorporeality' and the fluid boundaries between the human body and myriad nonhuman bodies and substances (Alaimo, 2010), we should likewise be aware of the life-enabling difference between bodies and their environments, as well as between human and natural ecosystems (Bergthaller, 2020).

It is true that in current ecological art, the human-nonhuman boundary is being transgressed in manifold ways in intriguing experiments that try to bring nonhuman agency into cognitive and aesthetic processes. When Jonathan Skinner mixes the human voice with the recorded songs of nightingales in his 'vibrational poetics' (Skinner, 2018), Tomás Saráceno builds whole exhibitions from spiderwebs (Saraceno, 2019), or Abigail Sanders transcribes whalesongs for the French horn (Sanders, 2021), these are just a few out of many attempts to bridge the human-nonhuman divide, which has brought about so much environmental degradation, in a 'sympoetic' imagination (Haraway, 2016) based on the awareness of multispecies co-existence. The visionary project Biotopia in Munich, which has developed from the more traditional Naturkundemuseum, likewise has this awareness at the programmatic core of its wide-ranging transdisciplinary design, with the aim of transmitting the knowledge of the environmental biosciences into society, education, and the larger public (https://www.biotopia.net/en/, 2021). Such experimental forms of science-inspired art, education, and museology are among the most important and fascinating areas of concern for the environmental humanities. Nevertheless, it is an epistemic as well as ethical premise of these experiments that these imaginative boundary-crossings are enacted and made possible within the conditioning frameworks of human intentions, institutions, and technologies of art.

To summarize: It seems to me that taking seriously an ecological perspective in all domains of science, culture, art, and literature, and acknowledging the co-agency of the nonhuman in epistemic, ethical, and aesthetic processes and creative practices, the environmental humanities need likewise to remain aware of the irreducible role and responsibility of humans in these activities and in the aim of working towards a more equitable, sustainable, and ecologically aware culture and society of the future. For this aim, an ecologically redefined humanism rather than an ecocentric posthumanism appears to supply a suitable conceptual framework. The new journal Ecohumanism seems to me to point in this direction by providing a scholarly forum in which the potentials and paradoxes of such a "non-anthropocentric humanism" (Iovino, 2010) can be explored for epistemic-creative transactions of the Anthropocene in literature, art, and the environmental humanities.

\section{References}

Adamson, J. (2012). Whale as cosmos: Multispecies ethnography and contemporary Indigenous cosmopolitics. Revista Canaria de Estudios Ingleses, 4, 29-45.

Adamson, J. (2018) (Ed.) The Green Humanities Lab: The Ecological and Digital Humanities. Resilience. 5.2 (Spring).

Alaimo, S. (2010). Bodily natures: Science, environment, and the material self. Bloomington University Press. Assmann, A. (2019). The future of cultural heritage and its challenges. In T. Meireis \& G. Rippl (Eds.), Cultural Sustainability: Perspectives from the Humanities and Social Sciences (pp. 25-35). Routledge. 
Atwood, M. (2003, 2009, 2013) Maddaddam Trilogy: Oryx and Crake. The Year of the Flood. Maddaddam. Bloomsbury.

Barad, K. (2007). Meeting the universe halfway: Quantum physics and the entanglement of matter and meaning. Duke University Press.

Bartosch, R. (2019). Literature, pedagogy, and climate change: Text models for a transcultural ecology. Palgrave Macmillan.

Bartosch, R. \& H. Zapf. (2021). "Teaching sustainable texts: The value of cultural ecology". In R. Bartosch (Ed.), Cultivating sustainability in language and literature pedagogy: Steps to an educational ecology (pp. 80-92), Routledge.

Bateson, G. (1973) Steps to an ecology of mind. Paladin.

Bayer, A. \& D. Seel. (Eds.) (2016). All dies hier, Majestät, ist Deins. Lyrik im Anthropozän. kookbooks.

Beck, U. (1998). World risk society - on the search for lost security. Polity.

Bergthaller, H. (2020). A tale of two systems: Anthropocene politics, Gaia, and the cybernetic Image of the planet. Ex-position. 44, 1-16.

Böhme, G. (2016). Aesthetics of nature - a philosophical perspective. In H. Zapf (Ed.) Handbook of Ecocriticism and Cultural Ecology (pp. 123-134), DeGruyter.

Braidotti, R. (2013). The posthuman. Polity.

Bryant, L. (2011). The democracy of objects. Open Humanities Press.

Clark, T. (2015). Ecocriticism on the edge: The Anthropocene as a threshold concept. Bloomsbury.

Comos, G. \& R. Rosenthal. (Eds.) (2019). Anglophone literature and culture in the Anthropocene. Cambridge Scholars.

Crutzen, P.J. \& E.F. Stoermer. (2000) The Anthropocene. International Geosphere-Biosphere Programme Newsletter 41 (May), 17-18.

Emmett, R. \& T. Lekan. (Eds.). (2016) Whose Anthropocene? Revisiting Dipesh Chakrabarty's "Four Theses." Munich Rachel Carson Center Perspectives.

Finke, P. (2006). Die Evolutionäre Kulturökologie. Hintergründe, Prinzipien und Perspektiven einer neuen Theorie der Kultur. Anglia. Journal of English Philology. 124.1, 175-217.

Foucault, M. (1984). L'ethique du souci de soi comme pratique de la liberté. Concordia. Revista international de folosofia. 6. July-Dec, 99-116 (My trans.) http://1libertaire.free.fr/MFoucault212.html

Gaard, G. (2015). Mindful new materialisms: Buddhist roots for material ecocriticism's flourishing. S. Iovino \& S. Oppermann (Eds.), Material Ecocriticism (pp. 291-300), Indiana University Press,.

Garrard, G (2017). Understanding climate scepticism: Global talking points, local singularities. Paper presented at the Augsburg Environmental Humanities Center in the framework of the DFG-research network Environmental Crisis and the Transnational Imagination.

Geerts, E. \& D. Carstens. (2019). Ethico-onto-epistemology. Pbilosophy Today. 63. 4 (Fall), 915-925.

Ghosh, A. (2004). The Hungry Tide. Harper Collins.

Habermas, J. (1990). Die Moderne - ein unvollendetes Projekt. [Modernity - an unfinished project]. Reclam. Haraway, D. (2016). Staying with the trouble: Making kin in the Chthulucene. Duke University Press.

Heise, U. (1997). Science and ecocriticism. American Book Review. 18.5 (July-August), 4.

Heise, Ursula. (2017). Imagining extinction: The cultural meanings of endangered secies. Chicago University Press.

Herbrechter, S. (2012). Posthumanism, subjectivity, autobiography. Subjectivity 5, 3. 327-347.

Horn, E. \& H. Bergthaller. (2019). Anthropozän zur Einfübrung. Junius.

Hustvedt, S. (2003). What I Loved. London: Hodder and Stoughton.

Hustvedt, S. (2013). Borderlands: First, second, and third person adventures in crossing disciplines.

Keynote Lecture at the American Studies Convention 2012. In A. Hornung (Ed.), American Lives. Universitätsverlag Winter, 111-135.

Iovino, S. (2010). Ecocriticism and a non-anthropocentric humanism: Reflections on local natures and global responsibilities. In L. Volkmann (Ed.), Local Natures, Global Responsibilities: Ecocritical Perspectives on New English Literatures (pp. 29-53), Rodopi,

Iovino, S. (2018). Ecocriticism and Italy. Bloomsbury.

Jasanoff, S., G. E. Markle, J. C. Petersen, \& Trevor Pinch (Eds.) (2007): Handbook of science and technology studies. Sage. 
Johnson, R. (2005). Locating non-western enlightenment texts for a global curriculum. International Association for Intercultural Education, 1-8

Latour, B. (2005). Assembling the social: An introduction to Actor Network Theory. Oxford University Press.

Latour, B. (2018). Down to earth: Politics in the new climate regime. Polity.

Mamic, I. (2016) Karen Barad's onto-ethico-epistemology: Aspects of empowerment in contextual theologies. Rhizomes: Cultural Studies in Emerging Knowledge, 30,1. http://www.rhizomes.net/issue30/mamic/index.html

Margulis, L. (1998). Symbiotic planet: A new look at evolution. Basic Books.

Mauch, C. (2019). Slow hope: Rethinking ecologies of crisis and fear. Munich Rachel Carson Center Perspectives.

Meireis, T. \& G. Rippl (Eds.) (2019) Cultural sustainability: Perspectives from the humanities and social sciences. Routledge.

Nicholas, G. (2019). An uneasy alliance: Indigenous traditional knowledge enriches science." The Conversation. February 18, 2019. https://theconversation.com/an-uneasy-alliance-indigenoustraditional-knowledge-enriches-science-109212 Accessed 27, 07, 2021.

Nida-Rümelin, J. (2016). Humanistische Reflexionen (Reflections on humanism). Suhrkamp.

Nida-Rümelin, J. (2018). Digitaler Humanismus. Eine Ethik für das Zeitalter der künstlichen Intelligenz. (Digital humanism: An ethics for the age of artificial intelligence) Piper.

Oppermann, S. \& S. Iovino. (Eds.) (2017) Environmental humanities: Voices from the Anthropocene. Rowman \& Littlefield.

Powers, R. (2018). The Overstory. London.

Rigby, K. (2016). Earth's poesy: Romantic poetics, natural philosophy, and biosemiotics. In H. Zapf (Ed.), Handbook of ecocriticism and cultural ecology (pp. 45-64), DeGruyter.

Robertson, R. (2021). The enlightenment: The pursuit of happiness 1680-1790. Harper Collins.

Rosa, H. (2018) Resonanz. Eine Soziologie der Weltbeziehung. (Resonance: A sociology of our relationship to the world.) Suhrkamp.

Said, E. (1978). Orientalism. Pantheon.

Said, E. (2004). Humanism and democracy. Palgrave Macmillan.

Said, E. (2006). West-eastern-divan.org/founders. Accessed July 25, 2021

Sarazeno, T. (2019). https://www.berliner-zeitung.de/kultur-vergnuegen/tomas-saraceno-ausstellunggalerie-schipper-berlin-spinnen-li.1839

Schaumann, C. \& P. Buchholz. (Eds.) (2021). Ecological archives. Special Issue of Colloquia Germanica. 53, 2-3.

Skinner, J. (2019) In Covert Lengthening Shadows. Poem presented at the 2019 Colloquium (Post-)Humanities. Academy of Sciences, Munich.

Steffen, W; Brodgate, W; Deutsch, L; Golfrey, O; \& Ludwig, C (2015). The trajectory of the Anthropocene: The Great Acceleration. The Anthropocene Review. 2 (1), 81-98.

Weik von Mossner, A. (2017). Affective ecologies: Empathy, emotion, and environmental narrative. Ohio University Press.

Wolfe, C. (2003). Animal rites: American culture, the discourse of species, and posthumanist theory. University of Chicago Press.

Yusoff, K. (2019). A billion Black universes or none. University of Minnesota Press.

Zapf, H. (2016a). Literature as cultural ecology: Sustainable texts. Bloomsbury.

Zapf, H. (2016b). (Ed.). Handbook of ecocriticism and cultural ecology. DeGruyter.

Zapf, H. (2019). The challenge of the Anthropocene and the sustainability of texts. In G. Comos \& C. Rosenthal (Eds.), Anglophone Literature and Culture in the Anthropocene (pp. 2-22), Cambridge Scholars.

Zapf, H. (2021). Cultural ecology, the environmental humanities, and the ecological archives of literature. In C. Schaumann and P. Buchholz (Eds.), Ecological Archives. Special Issue of Colloquia Germanica. 53, 121 139. 